\title{
Comparison of Guided Bone Regeneration using a Bovine Collagen Membrane vs a Calcium Sulfate Barrier
}

\author{
Mira Ghaly, David G Kerns, William W Hallmon, Eric S Solomon, William W Nagy \\ Ibtisam Al-Hashimi, Jeffrey A Rossmann
}

\begin{abstract}
Resorbable membranes have eliminated the need for re-entry for removal and reduce the incidence of adverse soft tissue reactions that accompany membrane exposure. However, the lack of rigidity often makes these more prone to collapse. Calcium sulfate has shown promise as a regenerative material alternative in a socket preservation application. The purpose of this study was to compare calcium sulfate and bovine collagen as a barrier in guided bone regeneration.

Materials and methods: Eighteen sites were treated in this randomized, blinded clinical study. Patients were divided into 2 groups, 9 sites each. Group 1, had bovine collagen membrane $\left(\right.$ Ossix ${ }^{\mathrm{TM}}$ ) and group 2 had calcium sulfate barrier (CalcigenOral ${ }^{\mathrm{TM}}$ ) to cover the graft. All sites were augmented with autogenously bone and demineralized freeze-dried bone composite graft at $1: 1$ ratio. Implants were placed in the grafted area 4 to 6 months post grafting. Vertical and horizontal ridge measurements were made before and after grafting by two blinded examiners.
\end{abstract}

Results: The collagen membrane group had a mean bone gain of $1.06 \pm 1.01 \mathrm{~mm}$ in width and $0.19 \pm 1.11 \mathrm{~mm}$ in height. In comparison, the calcium sulfate group had a mean bone loss of $-0.14 \pm 0.74 \mathrm{~mm}$ in width and $-0.19 \pm 0.74 \mathrm{~mm}$ in height. Student t-test revealed a significant difference in width dimension between the two groups, $p=0.01$.

Conclusion: Overall results of this study suggest that calcium sulfate might have limited use as barrier for ridge augmentation.

Keywords: Guided bone regeneration, Collagen membrane, Calcium sulfate, Membranes, Ridge augmentation.

How to cite this article: Ghaly M, Kerns DG, Hallmon WW, Solomon ES, Nagy WW, Al-Hashimi I, Rossmann JA. Comparison of Guided Bone Regeneration using a Bovine Collagen Membrane vs a Calcium Sulfate Barrier. J Contemp Dent 2013;3(3):138-143.

Source of support: Nil

Conflict of interest: None declared

\section{INTRODUCTION}

Guided bone regeneration (GBR) is based on the concept of creating a space that allows cells producing a desired type of tissue to grow while excluding undesired cell types. ${ }^{1}$ Often, clinical decisions made regarding what type of materials to use for GBR include: the type of bone or bone mixture, the type of membrane, and the use of growth factors. The critical criteria regarding membranes for GBR that have been established include: biocompatibility, cell occlusiveness, integration by the host tissues, clinical manageability and the space making function. ${ }^{2}$ In addition, the tissue reactions resulting from the resorption of bioresorbable membranes should be minimal, reversible and they should not adversely influence the regeneration of the desired tissues. ${ }^{3}$
Collagen membranes usually tolerate exposure and do not require a second stage surgery for their removal. They are hemostatic, chemotactic for fibroblasts, and are effective at inhibiting epithelial migration and promoting new connective tissue formation. ${ }^{4-8}$ Numerous authors reported on the successful use of collagen membranes in GTR and GBR procedures. ${ }^{9-18}$ One disadvantage of these membranes is a lack of rigidity.

Calcium sulfate (CS) consists of medical grade plaster of Paris (calcium sulfate alpha-hemihydrate) that hardens when set. Dreesman first reported the use of calcium sulfate as a bone graft material in 1892. Animal studies have shown CS to be osteoconductive. CS does not inhibit normal bone formation and has an average resorption rate of 4.7 weeks. ${ }^{19,20}$ CS has also been shown to support fibroblast migration, be occlusive to soft tissue, and is angiogenic. ${ }^{21-23}$ Many authors have reported on the successful use of calcium sulfate in human periodontal defects, extraction sockets, around implants and in sinus lift procedures. ${ }^{24-37}$ They reported that it was an effective barrier membrane, had angiogenic properties, served a hemostatic function, was an effective pharmaceutical/growth factor delivery vehicle and could be used in combination with other bone graft materials. ${ }^{38}$ Despite the widespread success of CS in several clinical applications, reports as to its use in guided bone regeneration for ridge augmentation are limited. The purpose of this study was to clinically compare CS vs bovine collagen as a membrane in GBR procedures in humans.

\section{MATERIALS AND METHODS}

Eighteen sites in 15 patients ( 7 men and 8 women) were evaluated in this randomized, blinded clinical trial. There were nine sites in the collagen membrane group and 9 sites in the CS group (Table 1). All sites were located in the maxilla and the posterior mandible (Table 2). None of the sites were located in the anterior mandible. All patients signed an informed consent to clinical research approved by The Baylor College of Dentistry Institutional Review Board for the Protection of Human Subjects. To enroll in the study patient must require a single implant in either maxilla or mandible. Patients with poor oral hygiene, smokers, history of head and neck radiation therapy, or serious systemic illness were excluded from the study.

A computer generated randomization determined whether sites would be augmented with collagen membrane 


\begin{tabular}{lcc}
\multicolumn{3}{c}{ Table 1: Patient distribution } \\
\hline & Collagen $(n=9)$ & $C^{*}(n=9)$ \\
\hline Male & 4 & 3 \\
Female & 5 & 6 \\
Age (mean \pm SD) & $36.3 \pm 15.8$ & $34.2 \pm 14.8$ \\
(range) years & $(18-62)$ & $(18-55)$ \\
\hline
\end{tabular}

${ }^{*} \mathrm{CS}$ : Calcium sulfate

\begin{tabular}{lcc}
\multicolumn{2}{c}{ Table 2: Site distribution } \\
& Collagen $(n=9)$ & $\mathrm{CS}^{*}(n=9)$ \\
\hline $\begin{array}{l}\text { Posterior maxilla } \\
\text { (1st molar to 1st premolar) }\end{array}$ & 5 & 3 \\
$\begin{array}{l}\text { Anterior maxilla } \\
\text { (canine to canine) }\end{array}$ & 3 & 2 \\
$\begin{array}{l}\text { Posterior mandible } \\
\text { (1st molar to 1st premolar) }\end{array}$ & 1 & 4 \\
\hline
\end{tabular}

${ }^{*} \mathrm{CS}$ : Calcium sulfate

(DFDBA + autogenous + collagen membrane), group 1, or with calcium sulfate barrier (DFDBA + autogenous + CS), group 2. Three blinded examiners not performing any of the surgeries made all clinical measurements during the course of the study (DGK, WWH, TWS). At least two examiners made measurements for each surgery. Measurements from the buccal-lingual and occlusoapical parts of the vacuum-formed retainer were taken to the nearest halfmillimeter with a University of North Carolina periodontal probe (Figs $1 \mathrm{~A}$ and $\mathrm{B}$ ). The measurements were repeated if they differed by more than $1 \mathrm{~mm}$ until the difference between the examiners was less than or equal to $1 \mathrm{~mm}$; then they were averaged, except for 51 of the 252 paired measurements $(20 \%)$ there was $>1 \mathrm{~mm}$ difference between the two examiners. The horizontal ridge augmentation procedure was performed according to the methods outlined by Buser et al. ${ }^{39,40} \mathrm{~A}$ full thickness flap was reflected and measurements to the exposed bony ridge were taken for height and width (buccal-lingual and occlusoapical). The cortical plate was perforated with a $1 / 2$ round bur in the area receiving the bone graft. DFDBA $(250-710 \mu \mathrm{m}$ cortical particles; LifeNet, Virginia Beach, Va) was hydrated in sterile saline and mixed 50:50 volume ratio with autogenously bone obtained with a Safescraper ${ }^{\circledR}$ (Biomet 3i, Palm Beach Gardens, FL). For group 1, 1 to $2 \mathrm{~mm}$ thick CS putty was placed over the grafted site and allowed to set. While group 2, the grafted was covered with collagen membrane. The flap was sutured with 5-0 polyglactin 910 sutures (Vicryl Rapide ${ }^{\mathrm{TM}}$, Ethicon, Cincinnati, OH).

Postoperatively, patients were prescribed amoxicillin $500 \mathrm{mg}$ three times daily for 7 days (clindamycin $150 \mathrm{mg}$ four times daily for 7 days was used in case of allergies to penicillin), ibuprofen $400 \mathrm{mg}$ every 4 to 6 hours for 2 days (then as needed) chlorhexidine $0.2 \%$ rinse $1 / 2 \mathrm{oz}$. twice daily for 3 weeks. The patients were seen on a weekly basis until
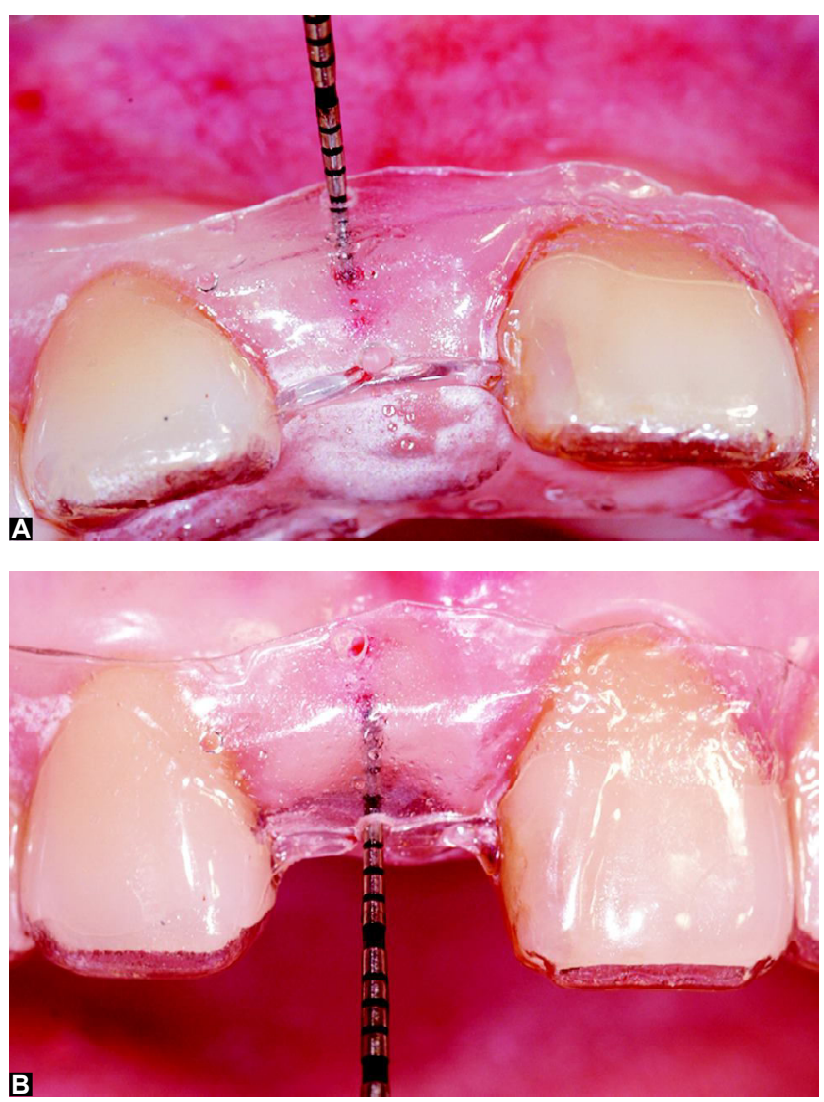

Figs 1A and B: Measurements taken with the UNC periodontal probe and the vacuum formed retainer: (A) buccal-lingual, (B) occlusoapical

soft tissue healing had occurred. Supragingival plaque was removed and oral hygiene was reinforced at these visits. The sutures were removed at 1 to 3 weeks.

After 4 to 6 months of healing, all the sites were re-entered and the implant was placed (Certain ${ }^{\circledR}$ Prevail $^{\circledR}$, Biomet 3i, Palm Beach Gardens, FL). The same blinded examiners repeated the buccolingual and occlusoapical measurements (Figs 2 and 3).

The primary variables evaluated were the increase in bone height occlusoapically and bone width buccal-lingually.

\section{RESULTS}

There was a significant correlation between the 2 evaluators for all measurements $(p=0.05$ and $p=0.01)$, which allowed averaging the measurements obtained by the 2 examiners. Table 3, shows changes in height and width for groups 1 and 2. There was a net gain in width and height for the collagen group; whereas there was a net loss in width and height for the CS group. Overall there was a significant in the width dimension between the two groups, $\mathrm{p}=0.01$.

\section{DISCUSSION}

The gains in ridge dimensions found in this study are less than those reported by Kirkland et al. When using a 

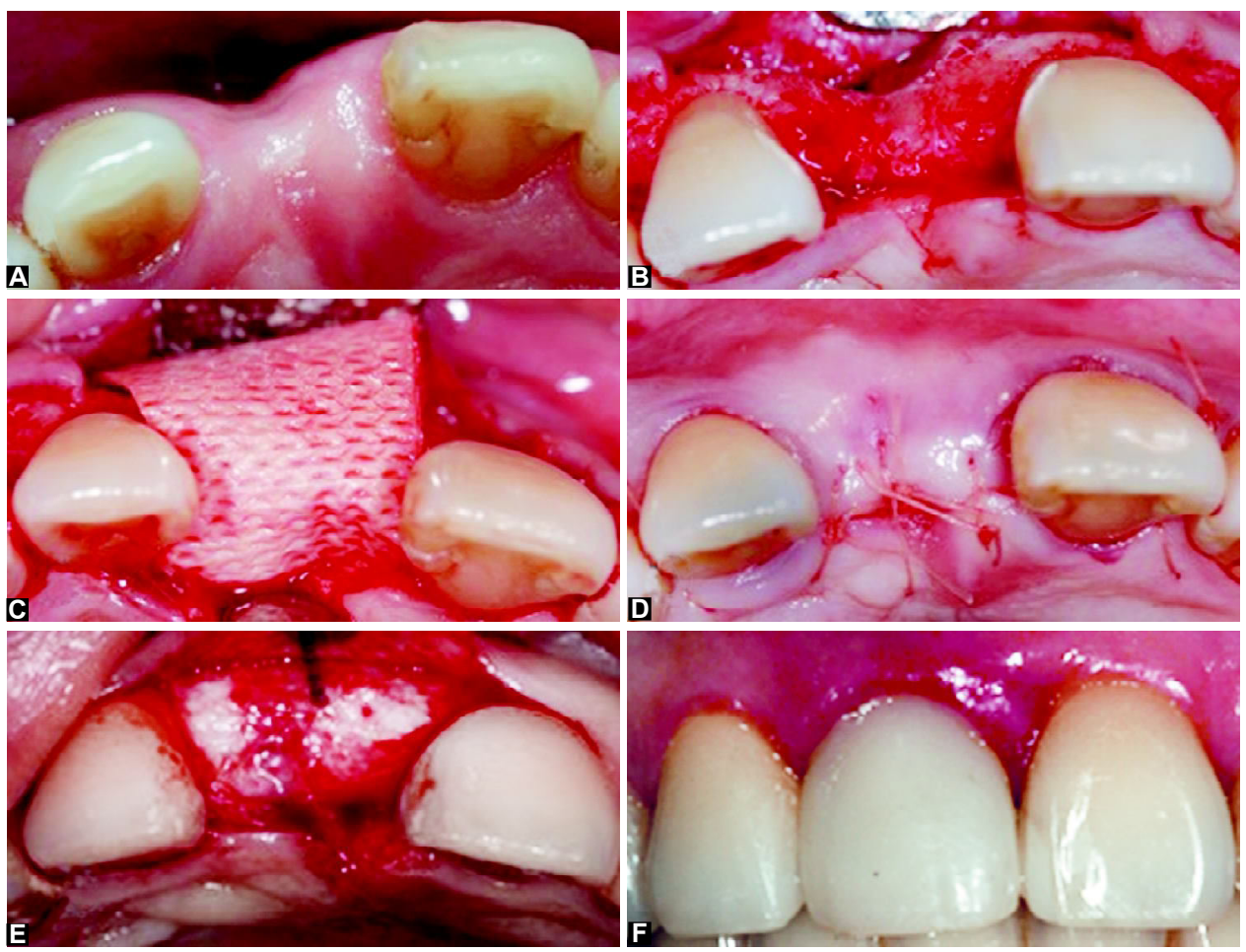

Figs 2A to F: GBR using bovine collagen membrane. (A) Initial occlusal view, (B) occlusal initial reflection, (C) bovine collagen membrane trimmed, hydrated and in place, (D) flap sutured, (E) 4 months postoperative occlusal view, $(F)$ temporary restoration buccal view
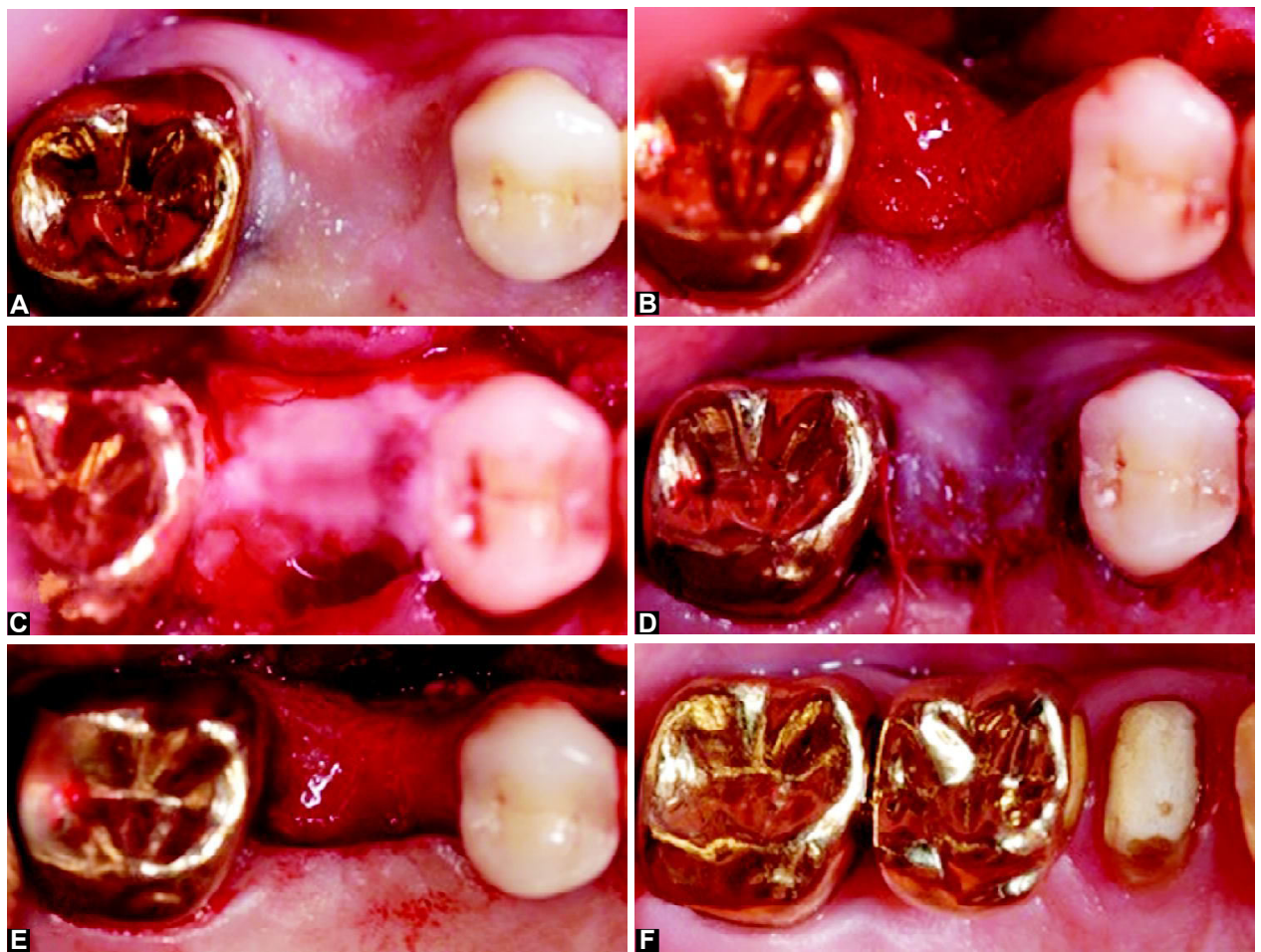

Figs 3 A to F: GBR using calcium sulfate barrier. (A) Initial occlusal view, (B) occlusal initial reflection, (C) calcium sulfate barrier placed over the bone graft, (D) flap sutured, (E) 4 months postoperative occlusal view, $(F)$ final restoration occlusal view

polylactide membrane over a composite bone graft consisting of DFDBA, bioactive glass and doxycycline hyclate granules to augment isolated alveolar ridge defects bordered by teeth. At 12 months, Kirkland et al determined there was an increase in ridge width of $3.3 \mathrm{~mm}$, and increase in ridge height of $1.9 \mathrm{~mm}$. They reported a decrease in soft 


\begin{tabular}{llll}
\multicolumn{4}{|c}{ Table 3: Comparison of mean difference in ridge height and width with collagen } \\
membrane vs calcium sulfate
\end{tabular}

tStudent's t-test

tissue thickness of $1.5 \mathrm{~mm}$ vertically and $1.96 \mathrm{~mm}$ horizontally ( $1.1 \mathrm{~mm}$ buccally and $0.8 \mathrm{~mm}$ lingually) based on bone sounding. ${ }^{41}$ These authors found a high correlation (0.98) between bone sounding and hard tissue measurements preoperatively. Consequently, the 12 months hard tissue and soft tissue measurements were based on bone sounding and not on re-entry. ${ }^{41}$ In this study, bone sounding measurements were within 0.36 to $0.89 \mathrm{~mm}$ of the open flap measurements with the difference being $<1 \mathrm{~mm}$ in $61 \%$ (postaugmentation buccal-lingual) to $100 \%$ (postaugmentation occlusoapical) of sites. This suggests a large variability in the accuracy of bone sounding. In reviewing the protocol of this study, BS may have been more accurate if an endodontic explorer was used to initially to pierce the soft tissue prior to taking the bone sounding measurement with the periodontal probe. This would reduce the possibility of soft tissue being compressed rather than pierced during these measurements (but could introduce the possibility of penetrating newly formed bone). Bone sounding is a relatively accurate way to measure the dimensions of the ridge both pre- and postridge augmentation procedures. Inaccuracies arise when confronted with a narrow ridge or a sloping crest and, in addition, newly formed bone may offer less/more resistance to probe penetration. Another suggestion to improve the accuracy of the measurements is the use of a hard acrylic stent rather than a flexible vacuum-formed retainer.

Simon et al found similar changes in ridge dimensions when using a polyglactide membrane over DFDBA for GBR in a case series of 19 extraction sites. At the 4-month re-entry, the authors reported a net gain of facial-palatal/ lingual width of 0.7 to $1.2 \mathrm{~mm}$. The authors concluded that the greater the amount of bone placed during the GBR procedure, the greater the net gain after healing and conversely, the greater the preoperative width, the less net gain in width after 4 months of healing. ${ }^{42}$ Therefore, the modest increases in ridge dimensions observed in the present study may be explained by the limited initial defect size. All of the ridges presented defects that may have been grafted simultaneously with the implant placement. However, due to the fact that calcium sulfate had never been clinically evaluated in a noncontained, ridge augmentation situation, it was deemed necessary to perform the implant surgeries in a staged approach.
Although, some authors have reported on the successful use of calcium sulfate as a barrier over noncomposite bone as well as a sole graft material/barrier, the clinical outcome may have been different had the calcium sulfate been mixed in with the bone graft. ${ }^{25,26,29,33,36,37,43}$ This may have made the composite graft more solid and reduced the risk of cracking of the barrier. It is also important to consider that the calcium sulfate barrier may have been too thin and may simply resorb too rapidly for effective GBR regardless of the added stability that mixing it with the bone graft may provide. A slowly resorbing calcium sulfate-based bone graft material may provide a better outcome. ${ }^{38,44}$

Although Andreana et al and De Leonardis et al successfully used calcium sulfate alone or in combination with a bone allograft for sinus lift procedures where minimal forces impact, GBRs may be subject to too much stress (food, tongue) for the calcium sulfate to remain intact. ${ }^{25,28}$ Nonetheless, CS still remains an accepted bone binding material when used in ridge preservation or GTR procedures. $^{24,26,27,29-37}$ It remains to be seen if modifying the protocol, as well as using the slowly resorbing calcium sulfate, may change the outcome for GBR.

\section{CONCLUSION}

Calcium sulfate has been shown to be useful for the treatment of periodontal defects, ridge preservation procedures and sinus lift procedures. However, the results of this study appear to support limited use of calcium sulfate as a membrane in guided bone regeneration procedures.

Biomet $3 \mathrm{i}$ Inc supported the study by donating Ossix ${ }^{\mathrm{TM}}$, Calcigen Oral $^{\mathrm{TM}}$ and implants.

\section{REFERENCES}

1. Melcher AH. On the repair potential of periodontal tissues. J Periodontol 1976;47:256-260.

2. Hardwick R, Scantlebury TV, Sanchez R, Whitley N, Ambruster $\mathrm{J}$. Membrane design criteria for guided bone regeneration of the alveolar ridge. In: Buser DA, Dahlen C, Schenk RK, editors. Guided bone regeneration in implant dentistry. Chicago: Quintessence 1994;101-136.

3. Gottlow J. Guided tissue regeneration using bioresorbable and non-resorbable devices: initial healing and long-term results. J Periodontol 1993;64:1157-1165.

4. Wang HL, Boyapati L. "PASS" principles for predictable bone regeneration. Implant Dent 2006;15:8-17. 
5. Chen CC, Wang HL, Smith F, Glickman GN, Shyr Y, O'Neal RB. Evaluation of a collagen membrane with and without bone grafts in treating periodontal intrabony defects. J Periodontol 1995;66:838-847.

6. Wang HL, MacNei RL. Guided tissue regeneration. Absorbable barriers. Dent Clin North Am 1998;42:505-522.

7. Wang HL, O'Neal RB, MacNeil LM. Regenerative treatment of periodontal defects utilizing a bioresorbable collagen membrane. Pract Periodontics Aesthet Dent 1995;7:59-66.

8. Wang HL, O'Neal RB, Thomas CL, Shyr Y, MacNeil RL. Evaluation of an absorbable collagen membrane in treating class II furcation defects. J Periodontol 1994;65:1029-1036.

9. Al-Arrayed F, Adam S, Moran J, Dowell P. Clinical trial of cross-linked human type I collagen as a barrier material in sugical periodontal treatment. J Clin Periodontol 1995;22:371-379.

10. Benque E, Zahedi S, Brocard D, Oscaby F, Justumus P, Brunel G. Guided tissue regeneration using a collagen membrane in chronic adult and rapidly progressive periodontitis patients in the treatment of 3-wall intrabony defects. J Clin Periodontol 1997;24:544-549.

11. Chung KM, Salkin LM, Stein MD, Freedman AL. Clinical evaluation of a biodegradable collagen membrane in guided tissue regeneration. J Periodontol 1990;61:732-736.

12. Evans GH, Yukna RA, Cambre KM, Gardiner DL. Clinical regeneration with guided tissue barriers. Curr Opin Periodontol 1997;4:74-81.

13. Mattson JS, McLey LL, Jabro MH. Treatment of intrabony defects with collagen membrane barriers. Case reports. J Periodontol 1995;66:635-645.

14. Quteish D, Dolby AE. The use of irradiated-crosslinked human collagen membrane in guided tissue regeneration. J Clin Periodontol 1992;92:476-484.

15. Iasella JM, Greenwell H, Miller RL, et al. Ridge preservation with freeze-dried bone allograft and a collagen membrane compared to extraction alone for implant site development: a clinical and histologic study in humans. J Periodontol 2003;74:990-999.

16. Zitzmann NU, Naef R, Scharer P. Resorbable versus nonresorbable membranaes in combination with Bio-Oss ${ }^{\mathrm{TM}}$ for guided bone regeneration. Int $\mathrm{J}$ Oral Maxillofac Implants 1997; 12:844-852.

17. Friedmann A, Strietzel FP, Maretzki B, Bernimoulin JP. Histological assessment of augmented jaw bone utilizing a new collagen barrier membrane compared to a standard barrier membrane to protect a granular bone substitute material. Clin Oral Implants Res 2002;13:587-594.

18. Friedmann A, Strietzel FP, Maretzki B, Pitaru S, Bernimoulin JP. Observations on a new collagen barrier membrane in 16 consecutively treated patients. Clinical and histological findings. J Periodontol 2001;72:1616-1623.

19. Bell WH. Resorption characteristics of bone and bone substitutes. Oral Surg Oral Med Oral Pathol Oral Radiol Endod 1964;17: 650-657.

20. Peltier LF. The use of plaster of Paris to fill large defects in bone: a preliminary report. 1959. Clin Orthop 2001;382:3-5.

21. Payne JM, Cobb CM, Rapley JW, Killoy WJ, Spencer P. Migration of human gingival fibroblasts over guided tissue regeneration barrier materials. J Periodontol 1996;67:236-244.

22. Pecora G, Andreana S, Margarone JE, Covani U, Sottosanti JS. Bone regeneration with a calcium sulfate barrier. Oral Surg Oral Med Oral Pathol Oral Radiol Endod 1997;84:424-429.

23. Strocchi R, Orsini G, Iezzi G, et al. Bone regeneration with calcium sulfate: evidence for increased angiogenesis in rabbits. J Oral Implant 2002;28:273-278.
24. Aichelmann-Reidy ME, Heath CD, Reynolds MA. Clinical evaluation of calcium sulfate in combination with demineralized freeze-dried bone allograft for the treatment of human intraosseous defects. J Periodontol 2004;75:340-347.

25. Andreana S, Cornelini R, Edsberg LE, Natiella JR. Maxillary sinus elevation for implant placement using calcium sulfate with and without DFDBA: six cases. Implant Dent 2004;13:270-277.

26. Anson D. Calcium sulfate: a 4-year observation of its use as a resorbable barrier in guided tissue regeneration of periodontal defects. Compendium 1996;17:895-899.

27. Couri CJ, Maze GI, Hinkson DW, Collins III BH, Dawson DV. Medical grade calcium sulfate hemihydrate versus expanded polytetrafluoroethylene in the treatment of mandibular class II furcations. J Periodontol 2002;73:1352-1359.

28. De Leonardis D, Pecora GE. Augmentation of the maxillary sinus with calcium sulfate: one-year clinical report from a prospective longitudinal study. Int J Oral Maxillofac Implants 1999;14:869-878.

29. Guarnieri R, Pecora G, Fini M, et al. Medical grade calcium sulfate hemihydrate in healing of human extraction sockets: clinical and histological observations at 3 months. J Periodontol 2004;75:902-908.

30. Harris RJ. Clinical evaluation of a composite bone graft with a calcium sulfate barrier. J Periodontol 2004;75:685-692.

31. Kim C-K, Chai J-K, Cho K-S, et al. Periodontal repair in intrabony defects treated with a calcium sulfate implant and calcium sulfate barrier. J Periodontol 1998;69:1317-1324.

32. Maragos P, Bissada NF, Wang R, Cole BP. Comparison of three methods using calcium sulfate as a graft/barrier material for the treatment of class II mandibular molar furcation defects. Int $\mathbf{J}$ Periodontics Restorative Dent 2002;22:493-501.

33. Orsini M, Orsini G, Benlloch D, et al. Comparison of calcium sulfate and autogenous bone graft to bioabsorbable membranes plus autogenous bone graft in the treatment of intrabony periodontal defects: a split-mouth study. J Periodontol 2001;72:296-302.

34. Setya AB, Bissada NF. Clinical evaluation of the use of calcium sulfate in regenerative periodontal surgery for the treatment of class III furcation involvement. Periodontal Clinical Investigations 1999;21:5-14.

35. Shaffer CD, App GR. The use of plaster of Paris in treating infrabony periodontal defects in humans. J Periodontol 1971;42:685-690.

36. Sottosanti JS. Calcium sulfate: a biodegradable and biocompatible barrier for guided tissue regeneration. Compend Contin Educ Dent 1992;8:226-234.

37. Vance GS, Greenwell H, Miller RL, Hill M, Johnston H, Scheetz JP. Comparison of an allograft in an experimental putty carrier and a bovine-derived xenograft used in ridge preservation: a clinical and histologic study in humans. Int J Oral Maxillofac Implants 2004;19(4):491-497.

38. Mamidwar SS, Ricci JL, Alezander H. Bone regeneration with calcium-sulfate-based bone grafts. Inside Dentistry 2006;Sep (Special Issue 2):2-7.

39. Buser DA, Dula K, Belser U, Hirt HP, Berthold H. Localized ridge augmentation using guided bone regeneration. II.Surgical procedures in the mandible. Int J Periodontics Restorative Dent 1995; 15:10-29.

40. Buser DA, Dula K, Belser U, Hirt HP, Berthold H. Localized ridge augmentation using guided bone regeneration. I.Surgical procedures in the maxilla. Int J Periodontics Restorative Dent 1993;21:29-45. 
41. Kirkland G, Greenwell H, Drisko C, Wittwer JW, Yancey J, Rebitski G. Hard tissue ridge augmentation using a resorbable membrane and a particulate graft without complete flap closure. Int J Periodontics Restorative Dent 2000;20: 383-389.

42. Simon BI, Von Hagen S, Deasy MJ, Faldu M, Resnansky D. Changes in alveolar bone height and width following ridge augmentation using bone graft and membranes. J Periodontol 2000;71:1774-1791.

43. Anson D. Using calcium sulfate in guided tissue regeneration: a recipe for success. Compendium 2000;21:365-376.

44. Gao C, Gao J, You X, et al. Fabrication of calcium sulfate/PLLA composite for bone repair. J Biomed Mater Res 2005;73A: 244-253.

\section{ABOUT THE AUTHORS}

\section{Mira Ghaly}

Private Practice of Periodontics, Ottawa, Ontario, Canada

\section{David G Kerns (Corresponding Author)}

Professor and Director, Postdoctoral Periodontics, Department of Periodontics, Baylor College of Dentistry, Texas A\&M University, Dallas Texas, USA, Phone: 214-828-8140, e-mail: dkerns@bcd.tamhsc.edu

\section{William W Hallmon}

Regents Professor and Chair (Retired), Department of Periodontics Baylor College of Dentistry, Texas A\&M University, Dallas Texas, USA

\section{Eric S Solomon}

Executive Director, Institutional Research, Professor, Public Health Sciences, Baylor College of Dentistry, Texas A\&M University, Dallas Texas, USA

\section{William W Nagy}

Professor and Graduate Program Director, Department of Prosthodontics, Baylor College of Dentistry, Texas A\&M University Dallas, Texas, USA

\section{Ibtisam Al-Hashimi}

Professor, Department of Periodontics, Baylor College of Dentistry Texas A\&M University, Dallas, Texas, USA

\section{Jeffrey A Rossmann}

Professor and Chair, Department of Periodontics, Baylor College of Dentistry, Texas A\&M University, Dallas, Texas, USA 